\title{
O nestalnim vrstama zavisnih rečenica u gramatikama italijanskog jezika
}

\author{
Marija M. Mitrović* \\ Univerzitet u Beogradu, Filološki fakultet, Katedra za italijanistiku
}

\section{Ključne reči: \\ zavisne rečenice \\ subordinacija \\ italijanski jezik}

\section{Apstrakt}

Italijanske gramatike pokazuju značajan stepen neujednačenosti kada su u pitanju teorijski model (tradicionalni, generativni i dependencijalni) i kriterijum za klasifikaciju zavisnih rečenica (formalni ili logički). Međutim, neujednačenost se primećuje i kada su u pitanju broj i vrste zavisnih rečenica, zbog čega se može govoriti o rečenicama koje oduvek čine obavezan deo klasifikacija i rečenicama čije je mesto u klasifikacijama nestalno. Cilj našeg rada jeste da prikažemo razvoj i zastupljenost nestalnih vrsta zavisnih rečenica $u$ gramatikama italijanskog jezika $u$ periodu od Sintassi dell'uso moderno (1881) Rafaela Fornačarija (Raffaello Fornaciari) do prvih decenija 21. veka. Pod nestalnim vrstama zavisnih rečenica podrazumevamo rečenice koje ne čine obavezan deo klasifikacija kod italijanskih gramatičara kao što su izrične, dubitativne, limitativne, količinske, zaključne, instrumentalne, imperativne, dodatne, suprotne, predikativne, poredbeno-uslovne, mesne, isključne i isključujuće. Takođe, prateći hronološku analizu, ispitaćemo razloge koji su doveli do toga da se određene nestalne vrste rečenica izgube iz klasifikacija (izrične, mesne), a da se, suprotno tome, neke druge vrste pojave, najpre sporadično, da bi do današnjih dana učvrstile svoje mesto u klasifikacijama. U radu će biti primenjen dijahronijski i sinhronijski pristup, a glavni metod istraživanja će biti analiza sadržaja. Rezultati istraživanja će pokazati da su starije klasifikacije bile siromašnije, kako funkcionalno tako i semantički, kao i razloge koji su doveli do izdvajanja novih vrsta. (примьено: 14. марта 2021; прихваћено: 14. августа 2021) www.anali.fil.bg.ac.rs АНАЛИ ФИЛОЛОНКОГ ФАКУЛТТА

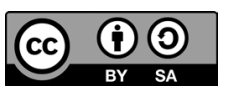

Filološki fakultet Katedra za italijanistiku Studentski trg 3 11000 Beograd, Srbija marija.mitrovic@fil.bg.ac.rs 


\section{Uvod}

Analiza gramatika italijanskog jezika pokazuje da su se gramatičari oduvek suočavali sa istim problemima pri klasifikacijama zavisnih rečenica, te da se pitanje klasifikacija rečenica može i dalje smatrati otvorenim ali $i$, najverovatnije, nerešivim i to iz više razloga. Naime, prema tradiciji, italijanski gramatičari su klasifikovali zavisne rečenice prema tzv. logičkom kriterijumu poistovećujući ih sa delovima proste rečenice (subjekat - subjekatska rečenica, objekat - objekatska rečenica, priloška odredba za vreme - vremenska rečenica, itd.) međutim sama priroda italijanskog jezika nalaže i tzv. formalnu klasifikaciju prema glagolskom načinu predikata zavisne rečenice (zavisne rečenice $u$ indikativu, konjunktivu, infinitivu, gerundijumu ili participu), zbog čega se vrlo često u gramatikama primenjuje dvostruki kriterijum klasifikacije. Od ova dva kriterijuma, italijanski gramatičari su češće pribegavali samo logičkom kriterijumu ${ }^{1}$, govoreći, međutim, uvek o pojedinačnim implicitnim rečenicama, dok su se određeni autori, mahom oni moderniji s kraja 20. ili početka 21. veka $^{2}$ koji jeziku pristupaju sa naučne strane (Renzi i dr., 1988; Salvi/Vanelli, 2004; Ferrari/Zampese, 2016), odlučivali za oba kriterijuma, pri čemu je kao glavni, primarni kriterijum istican formalni, dok je logički kriterijum uziman kao sekundarni.

Lingvisti često ističu nedovoljnost jedne klasifikacije odnosno nemogućnost potpunog opisivanja zavisnih rečenica u okviru samo jednog kriterijuma. Tako Serijani u svojoj gramatici, u uvodu poglavlja o zavisnim rečenicama, naglašava da nijedna tipologija nije zadovoljavajuća u potpunosti, te će stoga tokom svog izlaganja posebno tretirati svaku zavisnu rečenicu izbegavajući "nasilnu klasifikaciju“ u okviru opštih kategorija, ali će ipak po potrebi naglašavati njihovu analogiju sa odgovarajućim delom proste rečenice (Serianni, 1989: XIV.34).

S druge strane Herceg (Herczeg, 1959: 261) ističe da je pogrešno viđenje prema kom zavisne rečenice potiču od priloških odredaba, već je veća verovatnoća da su one, putem raznih faza transformacije, nastale od naporednih rečenica. Što se klasifikacija tiče, Herceg zauzima kritički stav prema postojećim klasifikacijama u italijanskim gramatikama u kojima se zavisne rečenice dele na onoliko grupa koliko ima i priloških odredaba. On precizira da se takvom klasifikacijom zanemaruje, na primer, pitanje hipotetičkih rečenica koje ne potiču ni od jedne priloške odredbe. Zbog toga on predlaže dve moguće klasifikacije: formalnu na osnovu veznika i značenjsku na osnovu značenja zavisne rečenice.

Drugo pitanje, pored kriterijuma, kada je reč o klasifikaciji zavisnih rečenica, jeste razlika između primarnih i sekundarnih klasifikacija zavisnih rečenica, kao i pitanje tačnog broja zavisnih rečenica, te da li je uopšte moguće odrediti koliko zavisnih rečenica postoji, na šta ćemo mi i pokušati da odgovorimo u centralnom delu ovog rada. Naime, pod primarnim klasifikacijama zavisnih rečenica podrazumevamo

1 Na primer, Batalja i Pernikone (Bataglia/Pernicone, 1951), Dardano i Trifone (Dardano/Trifone, 1983), Serijani (Serianni, 1988).

2 Ipak, neophodno je ovde pomenuti da je to slučaj i u Miljorinijevoj gramatici (Migliorini, 1941), što predstavlja još jedan u nizu razloga zbog kojih se ova gramatika može posmatrati kao iskorak ka savremenoj lingvistici. 
glavnu podelu rečenica u, najčešće, tri velike grupe: dopunske, pridevske, priloške Pod sekundarnim klasifikacijama podrazumevamo sve rečenice koje se klasifikuju kao podvrste dopunskih i priloških rečenica (pridevske tj. odnosne se po svojoj prirodi ne mogu deliti na dalje podvrste kao što je to slučaj sa ostale dve grupe).

Analizom gramatika italijanskog jezika primećeno je da su sekundarne klasifikacije vrlo neujednačene, te da je prilično značajan broj zavisnih rečenica koje nisu imale, iz različitih razloga, svoje stalno mesto u klasifikacijama, zbog čega smo ih mi okarakterisali upravo terminom nestalne vrste zavisnih rečenica ${ }^{4}$. Među njima možemo uočiti tri različite grupe: rečenice koje su se vremenom izgubile iz klasifikacija, rečenice koje se najpre pojavljuju sporadično da bi tek kasnije postale stalni deo klasifikacija i rečenice koje se više mogu posmatrati kao doprinos klasifikacijama pojedinačnih autora, a koje zapravo pokazuju da ne postoje stroge definicije niti čvrste granice među zavisnim rečenicama ${ }^{5}$. U okviru prve grupe izdvajamo izrične i mesne rečenice, u okviru druge limitativne, isključne, isključujuće, dodatne i suprotne, dok ćemo u okviru treće prikazati karakteristike tzv. količinskih, zaključnih, instrumentalnih, imperativnih izričnih, predikativnih, poredbeno-uslovnih, dubitativnih i rečenica adekvatnosti.

Korpus na kom je izvršena naša analiza čini 98 gramatika italijanskog jezika koje pripadaju periodu od 1881. do 2016. godine ${ }^{6}$. Korpusom su obuhvaćene kako najpoznatije gramatike italijanskog jezika, čiji autori su najpriznatiji italijanski lingvisti (Renzi i dr., 1988; Serianni, 1988; Dardano/Trifone, 1983; Bataglia/Pernicone, 1951) tako i savremene gramatike zasnovane na novim lingvističkim teorijama (Trifone/Palermo, 2000; Lo Duca/Solarino, 2004; Sabatini i dr., 2011; Ferrari/Zampese, 2016, itd.), ali i brojne školske i opšte gramatike manje poznatih autora.

\section{Analiza nestalnih vrsta zavisnih rečenica}

Izrične (it. dichiarative) i mesne (it. locative) rečenice pripadaju zavisnim rečenicama koje su vremenom, iz različitih razloga, izgubile svoje mesto u klasifikacijama italijanskih gramatika te ih savremene gramatike ${ }^{7}$ ne izdvajaju u svojim analizama.

3 Ova podela je danas uglavnom bipolarna i svodi se na rečenice koje su obavezne (pripadaju nukleusu) i rečenice koje imaju funkciju dodatka (nalaze se izvan nukleusa), dok se relativnim rečenicama daje posebno mesto u okviru gramatika budući da one ne dopunjuju glagol, već se odnose na neki nominalni element.

4 Nasuprot nestalnim vrstama zavisnih rečenica, možemo izdvojiti određeni broj rečenica koje se pojavljuju bez izuzetka u svim poglavljima o subordinaciji, zbog čega mogu biti okarakterisane kao „stalne vrste zavisnih rečenica“: odnosne, uzročne, namerne, vremenske, dopusne, posledične, uslovne, poredbene, načinske, zavisnoupitne, objekatske i subjekatske.

5 Tekavčić (1980: 2) naglašava da bi se čak moglo govoriti o razlici među „običnim“, „poznatim“, „glavnim“ ili, u najgorem slučaju, „pravilnim“ tipovima rečenica i „graničnim“, „mutnim“ ili „spornim“ vrstama pod kojima podrazumeva one koje je teško ili čak nemoguće smestiti u jedan od „pregradaka“ naše tradicionalne gramatičke analize, nasleđene još iz Antike.

6 Za početnu granicu istraživanja uzeto je delo Sintassi dell'uso moderno Rafaela Fornačarija (Fornaciari, 1881), tj. prvo delo posvećeno sintaksi, dok je krajnja granica godina kada je objavljena poslednja značajna gramatika italijanskog jezika švajcarskih italijanista A. Ferari i L. Campezea (Ferrari/Zampese, 2016).

7 Pod savremenim gramatikama italijanskog jezika podrazumevamo dela zasnovana na savremenim lingvističkim teorijama (generativnoj i dependencijalnoj gramatici) i razlikujemo ih od tradicionalnih gramatika zasnovanih na principima tradicionalne lingvistike. Više o razlici između tradicionalnih i savremenih gramatika u Andreoze 2017 (Andreose, 2017), Vaneli 2012 (Vanelli, 2012) i Kolombo i Grafi 2017 (Colombo/Graff, 2017). 
Naše istraživanje je pokazalo da su izrične rečenice prisutne isključivo u klasifikacijama gramatika tradicionalnog pristupa. Od ukupno 98 analiziranih gramatika, izrične rečenice su prisutne kod trideset i jednog autora, ali je takođe važno istaći da ih razmatraju svi najpriznatiji i najuvaženiji autori tradicionalne lingvistike (Battaglia/Pernicone, 1951; Dardano/Trifone, 1983; Serianni, 1988; Sensini, 1988, Trifone/ Palermo, 2000). Međutim, osim što mesto ovih rečenica u okviru subordinacije nije stalno i što ih mnogi autori izostavljaju iz klasifikacija, izrične rečenice se tumače, definišu i klasifikuju na vrlo različit način, te ćemo zato mi najpre pokušati da prikažemo njihovo mesto, a zatim i različita tumačenja ovih rečenica.

Izdvojili smo četiri načina klasifikacije izričnih rečenica u italijanskim gramatikama:

1. Izrične rečenice kao jedna od tri glavne grupe zavisnih rečenica. U okviru njih su u tom slučaju izdvojene subjekatske i objekatske rečenice, a vrlo često i zavisnoupitne. Ovaj tip klasifikacije u okviru koje su one, zapravo, izjednačene sa dopunskim rečenicama („dopunska“ i „izrična“ rečenica bi se u ovim delima mogle definisati kao sinonimi) zapazili smo u sedam gramatika (Messeri, 1894; Gilardi, 1903; Levi, 1903; Gualtieri, 1907; Scopa, 1920; Piazza, 1928; Calboli/Moroni, 1989).

2. Izrične rečenice kao poseban tip zavisnih rečenica u gramatikama u kojima nema primarnih grupa. U ovom slučaju se izrične rečenice ne smatraju ni podvrstom ni „nadvrstom“ nekog drugog tipa rečenica, već bivaju izdvojene kao posebna, samostalna vrsta u okviru subordinacije. Na ovaj način izrične rečenice su klasifikovane u devet gramatika (Coli/Rossi, 1930; Caioli/Chiari, 1938; Badiali/Facchini, 1962; Dardano/Trifone, 1983; Malvezzi, 1983; Serianni, 1988; Bisazza i dr., 1997; Perini, 2009; Panebianco i dr., 2012).

3. Izrične rečenice kao vrsta dopunskih rečenica. Ovaj način je u potpunoj suprotnosti sa tipom koji smo opisali pod brojem 1. U ovom slučaju izrične rečenice su u klasifikaciji izjednačene sa subjekatskim, objekatskim i zavisnoupitnim rečenicama i ovako ih posmatraju autori pet gramatika (Devoto, 1941; Sensini, 1988; Trifone/Palermo, 2000; Roncoroni, 2005; Castellaro, 2006).

4. Izrične rečenice kao podvrsta objekatskih i subjekatskih rečenica. Ovaj način posmatranja izričnih rečenica smo uočili u jednoj gramatici (Paniate, 1955), gde se uvodi izrično značenje objekatskih i subjekatskih rečenica odnosno objekatske i subjekatske rečenice koje izražavaju neki sud smatraju se izričnim rečenicama. S druge strane, Gojdanič (Goidanich, 1918) naglašava da se direktne objekatske rečenice kao i subjekatske rečenice uvedene bezličnim glagolima mogu zvati izričnim.

Postojanje izričnih rečenica $u$ italijanskim gramatikama se tumači na osnovu dva kriterijuma: semantičkog i formalnog. Važno je naglasiti da se nijedna od navedenih klasifikacije ne može poistovetiti u potpunosti sa nekim od ovih kriterijuma budući da se u svakoj od ovih klasifikacija mogu pronaći oba kriterijuma.

Kada je reč o semantičkom kriterijumu, izdvojili bismo starije gramatičare koji su smatrali da ove rečenice razjašnjavaju sadržaj glagola glavne rečenice (Messeri, 1894: 85; Gilardi, 1903: 158; Levi, 1903: 42; Gualtieri, 1907: 184) kao i gramatičare koji su smatrali da ove rečenice zavise isključivo od određenih grupa glagola ili određenih izraza (Colì/Rossi, 1930: 262; Badiali/Facchini, 1962: 403). 
Kada je reč o formalnom pristupu, određeni autori su smatrali da izrične rečenice zapravo objašnjavaju, najčešće, neku imenicu ili zamenicu iz upravne rečenice odnosno da imaju antecedent, pri čemu su pojedini u tom slučaju govorili i o apozicijskoj funkciji ovih rečenica. Ovakav pristup je prisutan uglavnom kod novijih autora (Caramello/Sarasso, 1959: 401; Ghiselli/Chiari, 1959: 494; Dardano/Trifone, 1983: 298; Malvezzi, 1983: 330; Serianni, 1988: XIV.78; Sensini, 1988: 473; Stoppelli, 1990: 377; Bisazza i dr., 1997: 423; Trifone/Palermo, 2000: 207; Roncoroni, 2005: 228; Patota, 2006: 451; Castellaro, 2006: 528; Perini, 2009: 197; Panebianco i dr., 2012: 242).

Uočili smo i određene „izolovane“ slučajeve u klasifikaciji ili definisanju izričnih rečenica. Na primer, Karamelo i Saraso (Caramello/Sarasso, 1959: 401) uvode tip takozvanih dodatih rečenica u okviru kojih izdvajaju izrične i odnosne rečenice. Kajoli i Kjari (Caioli/Chiari, 1938: 350) zastupaju neku vrstu semantičko-formalnog kriterijuma budući da ih definišu kao rečenice koje objašnjavaju glavnu rečenicu uvedene, međutim, isključivo veznicima cioè, ossia, infatti zbog čega su bliske naporednim rečenicama. Devoto (Devoto, 1941: 283) izrične rečenice posmatra prilično drugačije od ostalih autora s obzirom na to da ih pri definisanju povezuje sa određenim rečeničnim dopunama: specifikativnom dopunom subjekta i objekta i poredbenom dopunom. I najzad, Miljorini (Migliorini, 1941: 375), čija je ukupna klasifikacija rečenica znatno drugačija, izdvaja ih u okviru rečenica uvedenih veznikom che navodeći pritom primere objekatskih rečenica.

Obrađujući gramatički korpus za ovo istraživanje, došli smo do zaključka da je termin „izrična rečenica“ (it. proposizione dichiarativa) duboko ukorenjen u italijanskoj tradicionalnoj gramatici, pretpostavljamo zbog postojanja još u latinskoj gramatici, ali i nedovoljno dobro shvaćen i definisan. Mesto rečenica sa ovim nazivom u klasifikacijama je definisano kako sa semantičkog tako i sa formalnog stanovišta i uvek je bilo blisko dopunskim rečenicama, ali se ne može zaključiti da su se gramatičari usaglasili oko, na primer, terminološkog izjednačavanja dopunskih i izričnih rečenica jer su one zapravo često činile podvrstu dopunskih rečenica ili pak samo jednu od brojnih vrsta zavisnih rečenica koje su ipak bivale bliske objekatskim i subjekatskim rečenicama. Zbog te njihove bliske povezanosti sa dopunskim rečenicama, a i činjenice da nikada nije do kraja i u potpunosti defnisano njihovo mesto i značenje, zaključujemo da je termin i pojam izrične rečenice u italijanskoj gramatici nepotreban i suvišan zbog čega ga savremena sintaksa i odbacuje.

Kada je reč o mesnim rečenicama koje su takođe tekovina italijanske tradicionalne lingvistike, njihov razvoj i mesto u klasifikacijama su nešto drugačiji nego što je to slučaj sa izričnim rečenicama. Dok kod izričnih rečenica dolazi do potpunog gubitka termina i pojma, kod mesnih rečenica je zapravo došlo samo do promene kategorije budući da se ustalilo mišljenje prema kome ovakve rečenice treba posmatrati kao odnosne s obzirom na to da subordinatori sa mesnim značenjem (dove, ove, donde, onde) mogu imati funkciju odnosnih priloga. Ovi prilozi mogu uvesti prave odnosne rečenice koje se "oslanjaju“ na antecedent u upravnoj rečenici ali mogu uvesti i takozvane slobodne odnosne rečenice to jest odnosne rečenice bez antecedenta: 
(1) "La città dove vivo è Bologna" (Roncoroni, 2005: 231).

(2) "Sono entrato nella stanza dove era esposto il quadro" (Pompili, 1965: 298).

(3) "Vado dove vuoi" (Barbieri, 1971: 284).

(4) "Francesco gioca dove Michelina studia" (Tritto, 1973: 119)

Rečenice (1) i (2) su prave odnosne rečenice budući da imaju antecedente la città i nella stanza, dok su rečenice (3) i (4) slobodne odnosne rečenice u okviru kojih postoji mogućnost dodavanja priloga là (srp. tamo), te se stoga u tim slučajevima može govoriti o podrazumevanom antecedentu.

Budući da je, kao što smo mogli da vidimo, relativno značenje ovakvih rečenica nesporno, one su postale višak u klasifikacijama zavisnih rečenica dobivši svoje stalno mesto u okviru nepravih odnosnih rečenica (odnosne rečenice koje imaju određena priloška značenja: mesno, namerno, uzročno, itd.).

$\mathrm{S}$ druge strane, limitativne (it. limitative), isključne (it. eccettuative) $i$ isključujuće (it. esclusive) rečenice spadaju u grupu „graničnih“ slučajeva budući da se ove rečenice, ili bar pojedini njihovi subordinatori, mogu proučavati u okviru nekih većih, poznatijih, kategorija.

Isključujuće ${ }^{9}$ rečenice uvode neko „izuzimanje u odnosu na upravnu rečenicu“ (Serianni, XIV.239):

(5) "Ci siamo trovati d'accordo, senza che ne avessimo parlato prima"10 (Sabatini i dr., 2011: 397).

Razvojni put ovih rečenica u italijanskim gramatikama možemo vrlo lako pratiti budući da gramatičari, i kada ih nisu izdvajali zasebno, nisu zanemarivali značenje koje one izražavaju kao ni njihove subordinatore. Naime, Fornačari rečenice uvedene vezničkim izrazom senza che proučava u okviru načinskih rečenica naglašavajući, međutim, da označava „isključivanje neke okolnosti“ (Fornaciari, 1881: 221). Određeni potonji autori, među kojima i Ferari i Campeze (Ferrari/Zampese, 2016: 253), kao rečenicu sa modalnim značenjem posmatraju samo infinitivne rečenice uvedene veznikom senza (srp. a da ne), navodeći ipak da gotovo uvek imaju isključujuće značenje ili da se mogu nazvati isključujućim rečenicama. Tekavčić (1980: 3) navodi da se rečenice koje uvodi senza odnosno senza che najčešće ubrajaju u načinske rečenice, ilustrujući njihovu modalnost time što one odgovaraju na pitanje Come? (srp. kako?). Međutim, isti autor naglašava da ovakve rečenice Batalja i Pernikone (Bataglia/Pernicone, 1951) nazivaju ekskluzivnim, a ne načinskim.

8 „Grad gde živim je Bolonja“.

„Ušao sam u prostoriju gde je bila izložena slika“.

"Idem gde želiš“.

„Frančesko se igra gde Mikelino uči“.

9 Termin „isključujuće rečenice“ preuzet je iz Samardžić 2006, dok se u srpskoj sintaksi za značenje koje nose ovakve rečenice sreće termin „eksceptivno“ (Kovačević, 1998; Đurkin, 2018).

10 „Dogovorili smo se, a da nismo ranije razgovarali o tome“ (svi prevodi rečenica sa italijanskog na srpski jesu prevodi autora rada). 
S druge strane, isključne ${ }^{11}$ rečenice su definisane kao „rečenice koje ograničavaju sadržaj upravne“ (Sabatini i dr., 2011: 397), tj. „uvode neko sužavanje, uslovljavanje u odnosu na upravnu“ (Serianni, XIV.240):

(6) "Tutto posso credere, tranne che Giorgio sia innocente" .

(7) "Partiremo, a meno che non succeda qualcosa" (Sabatini i dr., 2011: 397) ${ }^{12}$.

Iako, prema našem mišljenju, ove rečenice ne pokazuju dovoljan stepen modalnosti da bismo ih posmatrali kao načinske rečenice, Fornačari njihove subordinatore salvo che, eccetto che, tranne che proučava upravo u poglavlju posvećenom načinskim rečenicama. Naime, za razliku od isključujućih rečenica, diskutabilno je da li isključne rečenice mogu odgovoriti na pitanje Come? (srp. kako?):

(8) Come ci siamo trovati d'accordo? Ci siamo trovati d'accordo senza che avessimo parlato prima.

(9) *Come partiremo? Partiremo, a meno che non succeda qualcosa.

(10) ${ }^{*}$ Come posso credere tutto? Tutto posso credere, tranne che Giorgio sia innocente ${ }^{13}$.

Primeri za isključne rečenice više odgovaraju na pitanje „pod kojim uslovom se nešto može dogoditi?" tako da se njihovo značenje zapravo približava limitativnom na šta upućuje i definicija Sabatinija i saradnika koja govori o ograničavanju sadržaja upravne rečenice, a tako su ih i posmatrali Pjaca (Piazza, 1928: 75) i Mocati i Saibene (Mozzati/Saibene, 1964: 225).

U prilog nedovoljnoj definisanosti isključujućih i isključnih rečenica govori i činjenica da su nekada proučavane u okviru jedne te iste kategorije (Masetti, 1965: 465; Colì/Rossi, 1930: 268). Iako se u klasifikacijama javljaju već početkom dvadesetog veka, zaključujemo da se njihovo mesto ustaljuje tek u drugoj polovini dvadesetog veka ${ }^{14}$.

Takozvane limitativne rečenice, koje se kod nekih autora spominju pod nazivom restriktivne, izdvaja i opisuje trećina autora našeg korpusa ${ }^{15}$. Navedeni autori

11 Ovaj tip zavisnih rečenica nije naročito zastupljen u srpskoj sintaksi ali se za opisivanje navedenog značenje može sresti termin „ekskluzivno“ (Kovačević, 1998; Đurkin, 2018). Termin „isključne rečenice“ preuzeli smo iz Samardžić 2006.

12 „Sve mogu da verujem, osim da je Đorđo nevin.“ „Krenućemo, osim ako se ne dogodi nešto."

13 Kako smo se dogovorili? Dogovorili smo se, a da nismo ranije razgovarali o tome.

*Kako ćemo krenuti? Krenućemo osim ako se ne dogodi nešto.

*Kako sve mogu da verujem? Sve mogu da verujem, osim da je Đorđo nevin.

14 De Titta 1902, Caioli/Chiari 1938, Magni 1946, Paniate 1955, Caramello/Sarasso 1959, Ghiselli/Chiari 1959, Badiali/Facchini 1962, Sivieri 1964, Panozzo 1964, Masetti 1965, Ciliberti 1972, Panozzo/Greco 1982, Dardano /Trifone 1983, Malvezzi 1983, Sabatini 1984, Altieri Biagi 1987, Serianni 1988, Sensini 1988, Calboli/Moroni 1989, Moretti/Consoni 1990, Stoppelli 1990, Moretti 1992, Alberti 1993, Bisazza i dr. 1997, Trifone/Palermo 2000, Lo Duca/Solarino 2004, Roncoroni 2005, Patota 2006, Prandi 2006, Castellaro 2006, Perini 2009, Sabatini i dr. 2011, Panebianco i dr. 2012.

15 Gilardi 1903, Levi 1903, Martina 1917, Scopa 1920, Piazza 1928, Colì/Rossi 1930, Finocchiaro 1935, Magni 
pod limitativnim rečenicama podrazumevaju zavisne rečenice koje sužavaju sadržaj upravne rečenice uvedene sledećim vezničkim izrazima per quello che, per quanto, quanto a, secondo che, secondo quanto. Implicitne rečenice uvedene su predlozima A ili PER iza kojih sledi infinitiv.

(11) "Secondo quanto mi ha detto, è ancora in vacanza" (Ferrari/Zampese, 2016: 253).

(12) "Per quello che (o Per quanto) ne dicono gli esperti, le risorse di petrolio si esauriranno" (Sabatini i dr., 2011: 387) ${ }^{16}$.

Međutim, autori koji ne uvode limitativne rečenice, vrlo slabo ili uopšte opisuju pomenute subordinatore. Na primer jedino je per quanto izdvojen u Renci i dr. (Renzi i dr., 1988: II 803) gde mu se pripisuje koncesivno značenje, dok Prandi (2011: 346-363) govori ujedno i o koncesivnom i limitativnom značenju ovog vezničkog izraza. S druge strane, implicitne rečenice uvedene predlogom PER, Tekavčić i Prandi (1980: 11; 2011: 342) tumače kao finalne.

Suprotne zavisne rečenice (it. avversative), koje su prisutne kod polovine autora našeg korpusa ${ }^{17}$, specifične su po tome što nose isti naziv kao i vrsta naporednih rečenica uvedenih veznicima $a$ i ali, kojima su i bliske u logičko-značenjskom smislu. Međutim, formalno gledano one su bliske zavisnim vremenskim rečenicama budući da ih u eksplicitnom obliku uvode zavisni veznici quando, quando invece, mentre, mentre che, laddove koji u tom slučaju imaju isključivo opozitivno, a nikako vremensko značenje s obzirom na to da ne mogu odgovoriti na pitanje Quando? (srp. kada?), ali se bez problema mogu zameniti naporednim suprotnim veznikom però ili ma u značenju „a, nego, već“:

(13) "Non fa che guardare la televisione, mentre dovrebbe studiare".

(14) "Fanno nuove autostrade, quando servono gli ospedali" (Lo Duca/Solarino, 2004: 172) ${ }^{18}$.

1946, Greco 1954, Duro 1955, Caramello/Sarasso 1959, Ghiselli/Chiari 1959, Diato/Mortara 1961, Panozzo 1964, Masetti 1965, Ciliberti 1972, Panozzo/Greco 1982, Sabatini 1984, Serianni 1988, Sensini 1988, Calboli/Moroni 1989, Moretti/Consoni 1990, Stoppelli 1990, Moretti 1992, Alberti 1993, Bisazza i dr. 1997, Trifone/Palermo 2000, Roncoroni 2005, Patota 2006, Castellaro 2006, Prandi 2006, Perini 2009, Sabatini i dr. 2011, Ferrari/ Zampese 2016.

16 „Prema onome što mi je rekao, još uvek je na odmoru“. „Prema onome što kažu eksperti, zalihe nafte će nestati“.

17 De Tita 1902, Gilardi 1903, Levi 1903, Martina 1917, Piazza 1928, Finocchiaro 1935, Brandonisio 1938, Caioli/ Chiari 1938, Magni 1946, Caramello/Sarasso 1959, Ghiselli/Chiari 1959, Diato/Mortara 1961, Galizzi/Verdina 1962, Badiali/Facchini 1962, Moretti/Consonni 1963, Sivieri 1964, Mozzati/Saibene 1964, Panozzo 1964, Alberti 1964, Dosio 1966, Marchese/Sartori 1970, Miot 1970, Ciliberti 1970, Panozzo/Greco 1982, Dardano/Trifone 1983, Sabatini 1984, Altieri Biagi 1987, Serianni 1988, Sensini 1988, Calboli/Moroni 1989, Moretti/Consoni 1990, Stoppelli 1990, Moretti 1992, Alberti 1993, Bisazza i dr. 1997, Trifone/Palermo 2000, Lo Duca/Solarino 2004, Roncoroni 2005, Patota 2006, Castellaro 2006, Perini 2009, Sabatini i dr. 2011, Panebianco i dr. 2012, Ferrari/ Zampese 2016.

18 "Samo gleda televiziju, a trebalo bi da uči“.

„Prave nove autoputeve, a potrebne su bolnice“. 
Implicitni oblik ovih rečenica uvode invece di i anziché (srp. umesto) koji pokazuju veći stepen samostalnosti od odgovarajućih eksplicitnih veznika budući da nemaju drugih značenja osim opozitivnog. Tekavčić (1980: 12) čak ide korak dalje tvrdeći da rečenice uvedene vezničkim izrazom invece di nemaju prosto adverzativno značenje, već značenje „neostvarenog očekivanja“ zbog čega ne mogu biti izjednačene sa suprotnim rečenicama.

Takozvane dodatne zavisne rečenice (it. aggiuntive) uočili smo u deset gramatika (Caramello/Sarasso, 1959; Panozzo/Greco, 1982; Serianni, 1988; Stoppelli, 1990; Moretti, 1992; Roncoroni, 2005; Patota, 2006; Castelaro, 2006; Perini, 2009; Ferrari/ Zampese, 2016).

(15) "Oltre a studiare assiduamente, fa anche molto sport"19 (Ferrari/Zampese, 2016: 254).

Karakteriše ih to što su prisutne kod prilično malog broja gramatičara, ali i činjenica da ostali autori potpuno zanemaruju ovaj subordinator i njegovo značenje i upotrebu.

U nastavku rada osvrnućemo se na zavisne rečenice koje predlažu jedan ili dvoje autora našeg korpusa izdvajajući ih, na osnovu semantičke komponente, iz neke od većih kategorija.

Rečenice adekvatnosti ${ }^{20}$ (it. di adeguatezza) pod tim nazivom izdvaja jedino Serijani naglašavajući da je termin preuzet iz Tekavčić (1972: II 455) ${ }^{21}$. Naime, ova vrsta zavisnih rečenica je, kako i sam autor naglašava, slična posledičnim rečenicama sa tom razlikom što kod njih posledica nije realizovana, već se odnosi na jedan određeni stepen inteziteta: $u$ upravnoj rečenici se javlja neki prilog za količinu ili odgovarajući pridev, dok je predikat zavisne rečenice, uvedene veznikom perché, u konjunktivu ili je, ukoliko je u pitanju implicitna rečenica, realizovan u vidu konstrukcije da ili per + infinitiv (Serianni, 1988: XIV.143). Jedan od primera za eksplicitnu rečenicu ovog tipa koji Serijani navodi je sledeći:

(16) “e poi trovava d'esser troppo adulto perché mio padre avesse ancora il diritto di prenderlo a schiaff" 22 .

Rečenice adekvatnosti (rečenice koje izražavaju primerenost, adekvatnost) zapravo predstavljaju neku vrstu mešavine namerne, posledične i količinske rečenice

19 „Pored toga što uči marljivo, bavi se mnogo i sportom“.

20 Kao ni ostale gramatike italijanskog jezika, ni najpoznatije gramatike srpskog jezika ne beleže ovaj tip rečenica tako da u srpskom jeziku ne postoji odgovarajući termin. Međutim, Tekavčić (1980) predlaže da se ove rečenice na srpskohrvatskom jeziku označe kao "rečenice adekvatnosti“ zbog čega ćemo i mi preuzeti taj termin.

21 "Il rapporto logico nel quale si esprime l'intensità della causa necessaria affinché si verifichi l'effetto. Il grado di intensità può essere adeguato (tanto $\mathrm{A}$ affinché $\mathrm{B}$ ) o non adeguato (troppo/troppo poco $\mathrm{A}$ affinché $\mathrm{B}$ ). Queste proposizioni hanno una componente comparativa e una finale o meglio di necessità, il che si vede nelle congiunzioni e nei modi. Proponiamo di chiamarle proposizioni di adeguatezza" (Tekavčić, 1972: 615).

22 „a i smatrao je da je previše odrastao da bi moj otac i dalje imao pravo da ga šamara." 
zbog čega Tekavčić (1980: 5-6) i predlaže za njih posebno mesto u klasifikacijama zavisnih rečenica. Detaljno ilustruje ovakav tip rečenica ${ }^{23}$ navodeći razloge zbog kojih ove rečenice treba smatrati posebnim tipom u okviru subordinacije, a ne vrstom posledičnih rečenica kako je to inače uobičajeno u gramatikama italijanskog jezika. Naime, Tekavčić precizira da ove rečenice ne iskazuju posledicu, već govore u kojoj meri je prisutan uzrok s obzirom na stepen potreban da bi izazvao posledicu i zaključuje da one sadrže namernu (sa formalne strane ${ }^{24}$ ), posledičnu i količinsku komponentu zbog čega i zaslužuju posebno mesto u klasifikacijama.

S druge strane, Ferari i Campeze (Ferrari/Zampese, 2016: 229) ih ne izdvajaju posebno, već u okviru posledičnih rečenica uvode poseban tip valutativno-konsekutivnih rečenica koje su uvedene prilozima i priloškim izrazima troppo, abbastanza, sufficientemente, insufficientemente, troppo poco, itd. ilustrujući ih sledećim primerima:

(17) "È troppo furbo per essere colto in trappola".

(18) "È abbastanza intelligente da/per capire da sola che non ce la può fare da sola"25.

Obratićemo pažnju na još neke primere nestalnih zavisnih rečenica koje svakako treba okarakterisati kao marginalne s obzirom na to da ih izdvajaju autori, uglavnom, starih školskih gramatika i to čvrsto se držeći principa logičke analize odnosno strogog izjednačavanja glagolskih dopuna i priloških odredbi sa zavisnim rečenicama. Sledeći takav kriterijum, autori su izdvajali količinske ${ }^{26}$ (it. quantitative), instrumentalne ${ }^{27}$ (it. strumentali) i predikativne ${ }^{28}$ zavisne rečenice (it. predicative). Pod zavisnim količinskim rečenicama podrazumevaju se rečenice uvedene upitnim prilogom quanto (srp. koliko) ${ }^{29}$ :

(19) “Non potrete mai sapere (...) quanto sia bella..." (Ugolini, 1941: 254).

Instrumentalne rečenice, izdvojene na osnovu rečenične dopune za sredstvo (it. complemento di mezzo o strumento), većina autora ne izdvaja kao samostalnu vrstu, već ih proučava u okviru načinskih rečenica. Međutim, autori koji ovim rečenicama

23 Na srpskohrvatskom jeziku ih ilustruje na sledeći način: previše/dosta/premalo A da bude B.

24 Veznik perché praćen glagolom u konjunktivu.

25 „Isuviše je lukav da bi bio uhvaćen u zamku.“

"Dovoljno je pametna da sama shvati da ne može da uspe sama.“

26 Termini 1914, Ugolini 1941.

27 Levi 1903, Termini 1914, Finocchiaro 1935, Caioli/Chiari 1938, Iori 1944, Magni 1946, Duro 1955, Paniate 1955, Ghiselli/Chiari 1959, Mozzati/Saibene 1964, Panozzo 1964, Ciliberti 1972, Panozzo/Greco 1982, Scarduelli i dr. 1983, Dardano/Trifone 1983, Sensini 1988, Moretti 1992, Alberti 1993, Bisazza i dr. 1997, Roncoroni 2005, Prandi 2006, Castellaro 2006, Panebianco i dr. 2012.

28 Scopa 1920, Moretti 1992

29 Ostali autori rečenice uvedene prilogom quanto opisuju u okviru zavisnoupitnih rečenica (Dardano/Trifone, 1989: 425; Ferarri/Zampese, 2016: 194).

30 „Nikada nećete moći da znate (...) koliko je lepa..... 
daju samostalno mesto u klasifikaciji napominju da one označavaju sredstvo za postizanje radnje i da, za razliku od načinskih koje odgovaraju na pitanje in che modo? (srp. na koji način?) odgovaraju na pitanje con che mezzo? (srp. kojim sredstvom?):

(20) "Si guasterà la salute col fumare tutte quelle sigarette"31 (Moretti, 1992: 520).

Predikativne rečenice Skopa (Scopa, 1920: 200) analizira u okviru izričnih rečenica pored subjekatskih, apozicijskih i objekatskih. Ne definiše ih, ali se kroz date primere uočava da ove rečenice imaju istu funkciju kao imenski deo predikata odnosno dopunjuju glagol biti. Moreti (Moretti, 1992: 456) ih izdvaja u okviru dopunskih rečenica naglašavajući da ovaj tip rečenica nije jako čest, te da se mogu naći uz kopulativne glagole essere, sembrare, parere, risultare. Moreti naglašava da je kopula sastavni deo predikativnih rečenica:

(21) "Questi ragazzi sembrano studiare con una certa superficialità."

(22) "La felicità è non cambiare"32 (Moretti, 1992: 456-7).

Kao što Moreti i navodi, ovakve strukture u italijanskom jeziku nisu česte zbog čega ih većina autora uopšte ne opisuje, a, takođe, upitna je i gramatičnost ovih rečenica, te najveća dekskriptivna gramatika italijanskog jezika ovakve konstrukcije označava kao agramatične (Renzi i dr., 1988: II 663).

Za razliku od rečenica koje su izdvojene prema kriterijumu logičke analize, imperativne $^{33}$ (it. imperative) i dubitativne ${ }^{34}$ (it. dubitative) izdvojene su iz okvira objekatskih rečenica na osnovu semantičkog kriterijuma odnosno značenja glagola koji ih uvode. Prve uvode glagoli tipa narediti, a druge glagoli koji izražavaju sumnju odnosno nesigurnost.

Takozvanu poredbeno-uslovnu rečenicu (it. comparative ipotetiche), kao zasebnu zavisnu rečenicu u okviru klasifikacije, izdvaja svega troje autora (Alberti, 1964; Dosio, 1966; Patota, 2006). Naime, pod poredbeno-uslovnim rečenicama ovi autori podrazumevaju rečenice uvedene oblicima come se/quasi/quasi che (srp. kao da):

(23) “Mi guardava come se (quasi) non mi avesse mai visto”35 (Patota, 2006: 457).

31 „Uništiće zdravlje pušeći sve te cigarete.“

32 „Ovi momci izgledaju kao da uče prilično površno.“

"Sreća je ne promeniti se."

33 Caramello/Sarasso 1959, Sensini 1988.

34 De Tita 1902, Brianzi 1905, Scopa 1920, Coli/Rossi 1930, Finocchiaro 1935, Caioli/Chiari 1938, Devoto 1941, Magri/Sferrazzo 1943, Paniate 1955, Badiali/Facchini 1962, Moretti/Consoni 1963, Mozzati/Saibene 1964, Alberti 1964, Dosio 1966, Ciliberti 1972.

35 „Gledao me je kao da me nikada nije video.“ 
Autori su ove rečenice, uglavnom, posmatrali kao poredbene (Serianni, 1988: XIV. 222) ili kao načinske ${ }^{36}$ (Dardano/Trifone, 1989: 428) naglašavajući, međutim, njihovu očiglednu hipotetičku nijansu.

I najzad, kao potpuno marginalnu i sasvim neutemeljenu vrstu zavisnih rečenica, pomenućemo takozvane zaključne zavisne rečenice (it. conclusive) budući da smo ih uočili u samo dve gramatike (Caioli/Chiari, 1938; Magni, 1946). Pod ovim rečenicama se podrazumevaju rečenice uvedene veznicima dunque, quindi, ebbene, pertanto, onde, perciò odnosno rečenice koje uvode neki zaključak u odnosu na glavnu rečenicu, međutim opšte je prihvaćeno da ovakve rečenice pripadaju koordinaciji, a Kajoli i Kjari (Caioli/Chiari, 1938: 350) i ističu da se one mogu smatrati i naporednim.

Prateći hronološku analizu zavisnih rečenica u italijanskim gramatikama, primećujemo da se prisustvo takozvanih nestalnih vrsta postepeno povećavalo kroz vremenski period koji smo analizirali. Primera radi, od ukupno devetnaest analiziranih gramatika koje pripadaju periodu od 1881. do tridesetih godina 20. veka, isključne i isključujuće rečenice smo zabeležili u svega dve gramatike dok dodatne rečenice nisu uopšte zabeležene. Nasuprot tome, od ukupno sedamnaest obrađenih gramatika poslednje decenije 20. i prvih decenija 21 . veka, isključne i isključujuće rečenice su zabeležene u petnaest, dok je analiza dodatnih rečenica zabeležena $u$ osam gramatika. Ovakav rezultat se objašnjava time što su pojedine vrste nestalnih zavisnih rečenica zapravo u starijoj italijanskoj gramatikografiji bile smatrane delom nekih drugih rečenica, kao što je to bio slučaj sa isključnim, isključujućim i dodatnim rečenicama, čije subordinatore Fornačari (Fornaciari, 1881: 221) opisuje u sklopu načinskih rečenica, dok ih Pjaca (Piazza, 1928: 75) i Mocati i Saibene (Mozzati/Saibene, 1964: 225) opisuju kao limitativne, ili se jednostavno stariji gramatičari nisu bavili značenjima određenih veznika i vezničkih izraza. S druge strane, analizirajući dela (ukupno 19) s kraja 19. i početka 20. veka mesne rečenice smo izdvojili u deset gramatika, dok ih u periodu od početka sedamdesetih do 2016. godine izdvaja svega sedam gramatičara od ukupno 38 analiziranih za ovaj period.

\section{Zaključak}

Na osnovu detaljnog uvida u korpus i analizu koja je za potrebe ovog rada sprovedena, možemo pretpostaviti da postoje tri razloga zbog kojih se pojavljuju nove vrste rečenica u italijanskim gramatikama.

Razlog koji bismo izdvojili kao primarni jeste razvoj samih sintaksičkih istraživanja i pokušaj da se izvrši sveobuhvatna analiza i opis zavisnih rečenica odnosno odgovarajućih subordinatora. To je razlog za pojavu rečenica koje su prisutne kod značajnog broja autora i koje su se održale do danas kako u tradicionalnoj tako i u savremenoj sintaksi (isključne, isključujuće, limitativne, suprotne).

36 Da li će ove rečenice biti definisane kao načinske ili poredbene, zavisi od toga kako gramatičari posmatraju veznik come (srp. kao). Dardano i Trifone (Dardano/Trifone, 1989: 428) ovaj veznik definišu modalnim i rečenice uvedene njime klasifikuju kao načinske, dok ga Serijani i Sensini ubrajaju među komparativne veznike, smatrajući, s druge strane, da načinske rečenice u italijanskom jeziku mogu biti samo implicitne sa predikatom u gerundijumu (Serianni 1988: XIV. 237; Sensini 2005: 456-457). 
S druge strane, uočili smo i pokušaj izdvajanje nekih sasvim nepotrebnih i neutemeljenih vrsta zavisnih rečenica kao što su količinske, predikativne i instrumentalne. Neutemeljenost ovih vrsta ogleda se, pre svega, u tome što ih izdvaja mali broj manje poznatih autora školskih gramatika, kao i u činjenici da nisu opisane kao posebne vrste rečenica ni u jednoj od značajnih gramatika italijanskog jezika. Razlog njihovog zasebnog opisivanja leži zapravo u strogoj vezanosti starijih autora za tradiciju i za princip logičke analize, tj. za strogo poistovećivanje delova proste rečenice i zavisnih rečenica. Količinske i instrumentalne nisu postale delom klasifikacija zbog toga što je jasna i neupitna njihova pripadnost nekim većim i opštepoznatim kategorijama (zavisnoupitnim i načinskim), dok je kod takozvanih predikativnih diskutabilno da li su takve konstrukcije, koje su u italijanskom jeziku inače slabo zastupljene, uopšte jezički prihvatljive.

Kao treći razlog, možemo pomenuti izdvajanje novih vrsta prema strogo semantičkom kriterijumu što je uočeno u slučaju takozvanih imperativnih i dubitativnih rečenica koje su zapravo samo semantički izdvojene iz kategorije objekatskih rečenica.

S druge strane, gramatičari su u slučaju mesnih i izričnih rečenica osetili suvišnost tih vrsta i postepeno ih odbacili. Za ove rečenice, na osnovu sprovedene analize, možemo zaključiti da predstavljaju isključivo tekovinu tradicionalne lingvistike, te da, iako ih neke po datumu novije gramatike opisuju (Sensini, 2005; Serianni i dr., 2011), u okviru savremenih sintaksičkih teorija ovim dvema kategorijama ne daje se posebno mesto u klasifikacijama, već se mesne opisuju u okviru odnosnih (iz razloga koje smo izneli na odgovarajućem mestu u ovome radu), dok se od pojma „izrična rečenica“ sasvim izvesno odustalo jer su to po svojoj formi i značenju objekatske ili subjekatske rečenice ${ }^{37}$, te su one samim tim u klasifikacijama suvišne.

Nakon izvršene obrade bogatog i raznovrsnog korpusa možemo zaključiti da su italijanske gramatike kroz istoriju pokazivale značajan stepen neujednačenosti kada su u pitanju broj i vrste zavisnih rečenica, ali i da savremene gramatike $u$ prilično velikoj meri ipak pokazuju ujednačenost u tom pogledu, kao i u pogledu kriterijuma za klasifikaciju zavisnih rečenica budući da se u okviru savremenih teorija prednost daje formalnom, a ne logičkom kriterijumu.

Ispitivanjem nestalnih odnosno manje zastupljenih zavisnih rečenica skreće se pažnja na postojanje mnogobrojnih nijansi u već tradicionalno ustaljenim i opštepriznatim sintaksičkim kategorijama, ali i nepotpunost klasifikacija mnogih autora. $\mathrm{S}$ tim u vezi, možemo dodati da bi ovaj rad mogao biti polazna tačka za neko drugo kontrastivno istraživanje u kome bi se, polazeći od italijanske sintakse, možda osvetlile neke nijanse u sintaksi zavisne rečenice srpskog jezika, a koje do sada nisu opisane i za koje, kako smo i videli u centralnoj analizi ovog rada, ne postoji odgovarajuća odnosno opšteprihvaćena terminologija.

37 Dardano i Trifone, iako ih izdvajaju kao posebnu grupu zavisnih rečenica, naglašavaju da se one mogu smatrati varijantom objekatskih i subjekatskih rečenica (Dardano/Trifone, 1989: 418). 


\section{Literatura}

Alberti, L. (1883). Grammatica della lingua italiana. Torino: Paravia.

Alberti, M. G. (1964). Grammatica della lingua italiana: studio condotto con metodo induttivo secondo i nuovi programmi ministeriali per la scuola media unica. Firenze: Sandron.

Alberti, A. Grammatica italiana. (1993). Milano: A. Vallardi.

Alessi, G., Manzoni, A. (1950). Grammatica della lingua italiana: per le scuole di avviamento professionale. Padova: Ape. An. Padovana Ed.

Altieri Biagi, M. L. (1987). La grammatica del testo: grammatica italiana e testi per le scuole medie superiori. Bologna: Ape.

Andorno, C. (2003). La grammatica italiana. Milano: Mondadori.

Andreose, A. (2017). Nuove grammatiche dell'italiano. Roma: Carocci.

Ardizzone, Z. (1949). Grammatica italiana. Napoli, Pozzuoli: D. Conte.

Badiali, P., Facchini, M. (1962). Parole vive: grammatica italiana per la scuola media. Bologna: Ponte Nuovo.

Barbieri, G. (1971). Le strutture della nostra lingua: grammatica italiana per la scuole superiori. Firenze: La Nuova Italia.

Battaglia, S., Pernicone, V. (1951). La grammatica italiana. Torino: Chiantore.

Bisazza, G., Mandurrino, G., Noris, F. (1997). Parole $\odot$ Metodo. Firenze: Sansoni.

Bianchi, E. (1943). La lingua italiana. Firenze: Salani.

Bologna, G. (1938). Grammatica italiana: Ad uso delle scuole medie. Volume unico. Regole ed esercizi. Roma: Albrighi, Segati e C.

Bottiglioni, G. (1914). Nuova grammatica italiana: per uso delle scuole ginnasiali, tecniche e complementari. Palermo: S. Biondo.

Brandonisio, M. (1935). Grammatica italiana: con esercizi ed appunti di stilistica e metrica: ad uso delle scuole medie inferiori. Bari: V. Romano.

Brianzi, A. (1905). Grammatica della lingua italiana. Livorno: Raffaello Giusti.

Caioli, E., Chiari, A. (1938). Grammatica della lingua italiana. Torino: G. Gambino.

Calboli, G., Moroni, G. (1989). Grammatica italiana: storia della scrittura, fonologia, morfologia, sintassi, lessico, metrica, retorica, nozioni di grammatica storica e di sociolinguistica. Bologna: Calderini.

Caramello, C., Sarasso, T. (1959). Come si dice... come si scrive... : grammatica italiana per la scuola media. Torino: Paravia.

Castellaro, R. (2006). Italiano insieme. Torino: Il Capitello.

Ciliberti, M. (1972). La lingua del sì: grammatica e uso della lingua italiana per la Scuola Media. Firenze: C. E. Giunti Bemporad Marzocco.

Colì, P. L., Rossi, G. (1930). Dolcissimo idioma: grammatica della lingua italiana per le scuole medie. Torino: Società editrice internazionale.

Colombo, A., Graffi, G. (2017). Capire la grammatica. Roma: Carocci.

Costabile, N. (1967). Le strutture della lingua italiana. Bologna: Patron.

Dardano, M., Trifone, P. (1983). La lingua italiana. Bologna: Zanichelli.

Dardano, M., Trifone, P. (1989). Grammatica italiana con nozioni di linguistica. Bologna: Zanichelli. 
Dardano, M., Trifone, P. (1997). La nuova grammatica della lingua italiana. Bologna: Zanichelli.

De Titta, C. (1905). Grammatica italiana della lingua viva: per uso delle scuole ginnasiali, tecniche e complementari. Lanciano: E. Carabba.

De Marco, S. (1953). Idioma italico: Grammatica italiana ad uso delle scuole di avviamento con appendice di esercizi supplementari. Volume unico. Padova: Ed. R.A.D.A.R.

Devoto, G. (1941). Introduzione alla grammatica: grammatica italiana per la scuola media. Firenze: La Nuova Italia.

Diatto, A., Mortara, R. (1961). Il dono della parola: grammatica italiana per la scuola media. Torino: G.B. Petrini.

Dosio, L. (1966). Armonie italiane: grammatica italiana, stilistica e metrica, panorama generale della storia della letteratura: ad uso del primo biennio degli istituti tecnici. Napoli: Morano.

Duro, A. (1955). Grammatica italiana: fonologia, morfologia, sintassi, lessico, brevi cenni di metrica. Torino: Paravia.

Ferrari, A., Zampese, L. (2016). Grammatica: parole, frasi, testi dell'italiano. Roma: Carocci.

Finocchiaro, A. (1935). Nuova grammatica italiana: Volume unico ad uso delle scuole medie inferiori. Bologna: C.E.L.I.

Finzi, G. (1910). Regole ed esercizi di grammatica italiana: ad uso delle scuole medie inferiori. Torino: S. Lattes.

Fochi, F. (1963). Dove il sì suona: grammatica della lingua italiana per la scuola media unificata. Milano: Mondadori.

Fornaciari, R. (1881). Sintassi italiana dell'uso moderno. Firenze: G. C. Sansoni.

Galizzi, G. P., Verdina, R. (1962). Parlare e scrivere: grammatica antologica della lingua italiana. Bergamo: Minerva Italica.

Gamberini, S. (1971). Il ragazzo guarda il mondo: grammatica trasformazionale della lingua italiana: per la scuola media. Messina: G. D’Anna.

Ghiselli, A., Chiari, A. (1959). Grammatica italiana. Firenze: Sansoni.

Gigli, M. (1818). Lingua filosofico-universale pei dotti. Milano: Società tipografica de' Classici italiani.

Gilardi, A. (1903). Grammatica italiana ad uso specialmente delle scuole ginnasiali. Milano: Tip. L. F. Cogliati Edit.

Goidanich, P. G. (1918). Grammatica italiana ad uso delle scuole: con nozioni di metrica, esercizi e suggerimenti didattici. Bologna: Zanichelli.

Greco, F. (1954). Grammatica italiana. Napoli: Istituto editoriale del mezzogiorno.

Gualtieri, V. G. (1907). Grammatica italiana per le scuole medie. Palermo: S. Andò.

Herczeg, G. (1959). Sintassi delle proposizioni subordinate nella lingua italiana (studio di grammatica descrittiva). Budapest: Pubblicazioni dell'istituto italiano dell'università di Budapest.

Jori, U. (1944). La grammatica in azione: grammatica italiana per le scuole medie inferiori; collegata con l'analisi logica e con la morfologia latina, con l'etimologia, con le comparazioni di costrutti italiani e latini. Padova: Zannoni.

Lazzeroni, E. (1941). Grammatica italiana ad uso della scuola media. Palermo: G. Priulla. 
Levi, E. (1907). Grammatica italiana. Livorno: Raffaello Giusti.

Lo Duca, M. G., Solarino, R. (2004). Lingua italiana: una grammatica ragionevole. Padova: Unipress.

Magri, D., Sferrazzo, A. (1943). Grammatica italiana per la scuola media. Torino: Società editrice internazionale.

Masetti, U. (1965). Armonie della lingua: grammatica italiana per gli istituti tecnici di ogni tipo. Messina, Firenze: Casa Editrice G. D’Anna.

Malvezzi, F. (1983). Grammatica italiana. Roma: Dante Alighieri.

Magni, M. (1946). Grammatica italiana. Milano: Casa editrice la Prora.

Marchese, A., Sartori, A. (1970). Il segno, il senso: grammatica moderna della lingua italiana ad uso delle scuole medie superiori. Milano: Principato.

Martina, M. (1917). Grammatica pratica e retorica della Lingua italiana, per le scuole ginnasiali, tecniche, complementari e normali. Torino: Libr. Ed. Internazionale.

Messeri, A. (1894). Grammatica razionale italiana. Torino: Paravia.

Migliorini, B. (1941). La lingua nazionale: avviamento allo studio della grammatica e del lessico italiano per la scuola media. Firenze: Le Monnier.

Miot, G. (1970). Grammatica italiana: per le scuole medie superiori. Roma: O. Barjes.

Moretti, G. B. (1992). L'italiano come Prima o Seconda Lingua nelle sue varietà scritte e parlate. Perugia: Guerra.

Moretti, M., Consonni, D. (1963). Lingua madre: grammatica italiana moderna. Torino: Società Editrice Internazionale.

Moretti, M., Consonni, D. (1990). Nuova grammatica italiana. Torino: SEI.

Mozzati, A., Saibene, C. (1964). Parole e idee: grammatica italiana per la scuola media. Torino: G.B. Petrini.

Panebianco, B., Pisoni, C., Reggiani, L. (2012). Grammatica italiana: con esercizi di autoverifica. Bologna: Zanichelli.

Paniate, E. (1955). Grammatica viva della lingua italiana: studio pratico del lessico, avviamento alla composizione: per la scuola media. Torino: S. Lattes.

Panozzo, U. (1964). Il nostro discorso: grammatica ragionata della lingua italiana per la scuola media. Firenze: Le Monnier.

Panozzo, U., Greco, D. (1982). La struttura della lingua italiana: grammatica, sintassi, stilistica per il primo ciclo delle scuole medie superiori. Firenze: Le Monnier.

Panzini, A., Allulli, R. (1950). Grammatica italiana e introduzione allo studio del latino. Milano: Mondadori.

Parato, G. (1923). Nuova grammatica della lingua italiana: con brevi nozioni intorno ai principali generi di composizione ad uso delle scuole. Torino: Paravia.

Parisi, D., Antinucci, F. (1973). Elementi di grammatica. Torino: Boringhieri.

Patota, G. (2006). Grammatica di riferimento dell'italiano contemporaneo. Milano: Garzanti.

Perini, E. (2009). Grammatica italiana per tutti. Milano: Giunti.

Piazza, E. (1928). Grammatica italiana ad uso delle scuole medie: Sintassi-ortografia, Vol. II. Livorno: Giusti.

Pompili, L. (1965). Grammatica della lingua italiana: ortoepia, ortografia, morfologia, sintassi, lessico, stilistica, metrica, letteratura. Milano: Signorelli. 
Prandi, M. (2006). Le regole e le scelte: introduzione alla grammatica italiana. Torino: UTET.

Prandi, M., De Santis, C. (2011). Le regole e le scelte. Manuale di linguistica e di grammatica italiana. Torino: Utet.

Renzi, L., Salvi, G., Cardinaletti, A. (1988-1995). Grande grammatica italiana di consultazione, 3 vol. Bologna. Il Mulino.

Roncoroni, F. (2005). Grammatica essenziale della lingua italiana. Milano: Oscar Mondadori.

Sabatini, F. (1984). La comunicazione e gli usi della lingua: pratica, analisi e storia della lingua italiana: scuole secondarie superiori. Torino: Loescher.

Sabatini, F., Camodeca, C., De Santis, C. (2011). Sistema e testo: dalla grammatica valenziale all'esperienza dei testi. Torino: Loescher.

Salvi, G., Vanelli, L. (1992). Grammatica essenziale di riferimento della lingua italiana. Novara: Istituto geografico De Agostini, Le Monnier.

Salvi, G., Vanelli, L. (2004). Nuova grammatica italiana. Bologna: Il Mulino.

Saltarelli, M. (1970). La grammatica generativa trasformazionale: con introduzione alla fonologia, sintassi e dialettologia italiana. Firenze: Sansoni.

Santini, E., Cognetti, L. (1948). Grammatica italiana ad uso della scuola media. Palermo: Palumbo.

Samardžić, M. (2006). Od rečenice do teksta. Uvod u sintasku italijanske složene rečenice. Podgorica: Filozofski fakultet Univerziteta Crne Gore.

Satta, L. (1971). La prima scienza: grammatica italiana per il biennio delle scuole medie superiori. Messina, Firenze: G. D’Anna.

Scarduelli, T., Achiardi, G., Barbi, S. (1983). Lingua e grammatica: teoria della lingua e grammatica italiana. Milano: Principato.

Scopa, G. (1920). Grammatica italiana esposta con nuovo metodo per uso delle scuole medie inferiori: morfologia e sintassi. Torino: Paravia.

Sensale, M., Valenza, P. (1962). Dal periodo alla parola: grammatica italiana intuitiva per la scuola media unificata. Padova: Editr. RADAR.

Sensini, M. (1988). Le parole e il testo: teoria e pratica della comunicazione linguistica: grammatica italiana per le scuole medie superiori. Milano: Mondadori.

Sensini, M. (2005). La lingua e i testi. La riflessione sulla lingua. Milano: Arnoldo Mondadori Scuola.

Serianni, L. (1988). Grammatica italiana: italiano comune e lingua letteraria: suoni, forme, costrutti (con la collaborazione di Alberto Castelvecchi). Torino: UTET.

Serianni, L., Patota, G., Della Valle, V., Schiannini, D. (2011). Lingua comune. La grammatica e il testo. Milano: Edizioni scolastiche Bruno Mondadori.

Sivieri, A. (1964). Grammatica italiana: per la scuola media. Milano: Principato.

Soave, F. (1817). Gramatica ragionata della lingua italiana (1. ed. 1771). Milano: Società tipografica de'classici italiani.

Stoppelli, P. (1990). La parola in gioco: grammatica della lingua italiana per la scuola media. Milano: Garzanti.

Tekavcic, P. (1972). Grammatica storica dell'italiano, Vol. II. Bologna: Il Mulino. 
Tekavčić P. (1980). O neki „posebnim“ tipovima rečenica: prilog problemu klasifikacije. Strani jezici: časopis za unapređenje nastave stranih jezika, 9(1), 2-13.

Termini, F. A. (1914). Grammatica moderna della lingua italiana. Palermo: A. Trimarchi. Trabalza, C., Allodoli, E. (1934). La grammatica degl'italiani. Firenze: Le Monnier.

Tritto, F. (1973). La dinamica del linguaggio: grammatica operativa e produttiva della lingua italiana ad uso della scuola media. Padova: R. A. D. A. R.

Trifone, P., Palermo, M. (2000). Grammatica italiana di base. Bologna: Zanichelli.

Trombetti, A. (1918). Grammatica italiana, ad uso delle scuole. Milano: Soc. Ed. Dante Alighieri di Albrighi.

Vanelli, L. (2010). Grammatiche dell'italiano e linguistica moderna. Padova: Unipress.

Vanni, M. (1925). Ripetizione della grammatica italiana nello studio delle tre analisi: Grammaticale della parola. Logica della proposizione. Logica del periodo. Prospetti e letture di esercizio... per le prime scuole medie. Milano: C. Signorelli.

Ђуркин, В. (2018). Сложени зависни везници у српском језику (и юихова функционалностилска дистрибуција). Београд: Јасен.

[Đurkin, V. (2018). Složeni zavisni veznici u srpskom jeziku (i njihova funkcionalnostilska distribucija). Beograd: Jasen]

Ковачевић, М. (1998). Синтакса сложене реченице у српском језику. Београд, Србиње: Рашка школа, Српско просвјетно и културно друштво Просвјета.

[Kovačević, M. (1988). Sintaksa složene rečenice u srpskom jeziku. Beograd, Srbinje: Raška škola, Srpsko prosvjetno i kulturno društvo Prosvjeta]

\section{Marija M. Mitrović}

\section{Summary}

\section{ON THE INFREQUENT SUBORDINATE PHRASES IN THE GRAMMARS OF THE ITALIAN LANGUAGE}

The objective of this paper is to present the development and presence of infrequent subordinate sentences in Italian grammars from Fornaciari (1881) up to the early decades of the 2000s. The so-called infrequent subordinate phrases would be those dependent phrases that are not always found in the classifications of Italian grammarians, such as declarative, dubitative, limiting, quantitative, conclusive, instrumental, imperative, additional, aversive, predicative, hypothetical comparative, locative, exclusive and excepting. It is also possible to subdivide them further on the basis of their frequency in grammars: those examined by a significant number of grammarians (aversive, exclusive, excepting) and those considered to be more of a personal contribution of a certain author (quantitative, predicative, imperative, comparative hypothetical). Following a chronological analysis, on the one hand we will analyze the reasons why some of the subordinate ones got lost from the classifications and, on the other hand, the reasons why the others appeared. The results will show that older grammar classifications are 
poorer, both formally and semantically. In addition, the results will show the reasons why the new dependent sentence types were identified.

\section{Key words:}

dependent phrases, subordination, Italian

\section{Riassunto}

\section{SULLE FRASI SUBORDINATE INFREQUENTI NELLE GRAMMATICHE DELLA LINGUA ITALIANA}

L'obiettivo del presente contributo è di presentare lo sviluppo e la presenza di frasi subordinate infrequenti nelle grammatiche della lingua italiana dal Fornaciari (1881) fino ai primi decenni del Duemila. Le cosiddette subordinate infrequenti sarebbero quelle frasi dipendenti che non si riscontrano sempre nelle classificazioni dei grammatici italiani, quali dichiarative, dubitative, limitative, quantitative, conclusive, strumentali, imperative, aggiuntive, avversative, predicative, comparative ipotetiche, locative, esclusive, eccettuative. E' possibile suddividere ulteriormente anche esse in base alla loro frequenza nelle grammatiche: quelle esaminate da un numero rilevante di grammatici (avversative, esclusive, eccettuative) e quelle da considerare più un contributo personale di un certo autore (quantitative, predicative, imperative, comparative ipotetiche). Seguendo un'analisi cronologica, da una parte analizzeremo le ragioni per cui alcune di quelle subordinate si sono perse dalle classificazioni e, d'altra parte, le ragioni per cui le altre ci sono apparse. I risultati mostreranno che le classificazioni delle grammatiche più datate sono più povere, sia formalmente che semanticamente, nonché le ragioni per cui sono stati individuati i nuovi tipi di frasi dipendenti.

\section{Parole chiave:}

frasi dipendenti, subordinazione, lingua italiana 